\title{
Application of Diabetes Self Management Education (DSME) in Patients with Type 2 Diabetes Mellitus based on Blood Glucose Levels
}

\author{
Andi Akifa Sudirman ${ }^{1}$, Dewi Modjo ${ }^{1}$ \\ ${ }^{1}$ Nursing Science, Muhammadiyah University of Gorontalo, Indonesia \\ Received: October 18, 2020 \\ Revised: October 26, 2020 \\ Accepted: October 28, 2020
}

\begin{abstract}
Diabetes Self Management Education (DSME) uses guidelines, counseling, and behavioral intervention methods to increase knowledge about diabetes and improve individual and family skills in managing diabetes mellitus (DM). This research is a quantitative study using a pre-experimental design that provides treatment or intervention to the research subjects then the effect of the treatment is measured and analyzed. This design is used to compare the results of the intervention of the application of Diabetes Self Management Education (DSME) on controlling blood glucose levels in patients with type 2 diabetes mellitus. The analysis used the dependent t-test/paired t-test. The results showed that there were significant differences in blood glucose levels in the measurement after giving DSME to the respondents, indicating that the measurement of blood glucose levels after treatment was smaller than the measurement before treatment. It is necessary to develop a program to increase the competence of nurses in nursing care for diabetic clients and education related to diabetic self-care to increase the knowledge and skills of nurses in managing diabetes.
\end{abstract}

Keywords: Diabetes Self Management Education, Diabetes Mellitus, Blood Glucose Levels.

\section{Introduction}

Diabetes mellitus (DM) is a progressive chronic disease characterized by the inability of the body to metabolize carbohydrates, fats, and proteins, leading to hyperglycemia (high blood glucose levels). Although hyperglycemia plays an important role in the development of complications associated with DM, high levels of blood glucose are only one component of the pathological process, and clinical manifestations associated with DM. (Sudirman, 2018) .

Various epidemiological studies have shown an increasing trend in the incidence and prevalence of type $2 \mathrm{DM}$ in various parts of the world. WHO and the International Diabetes Federation (IDF) predict an increase in the number of people with DM even though there are differences in prevalence rates, both reports show an increase in the number of people with DM by 2-3 times in 2030 (Perkeni, 2015).

Diabetes mellitus is a progressive disease that causes various complications, both acute and chronic, if not managed properly, it can lead to various chronic complications (Bastaki, 2005; Patel et al., 2012). Efforts to heal back to normal are very difficult if things have occurred because the damage will generally be permanent. Prevention efforts are needed early to overcome these complications and it is hoped that it will be very useful to avoid various unfavorable things. Without effective intervention, type 2 diabetes will increase, which is due to increased life expectancy, reduced mortality from infectious diseases, and increased risk factors due to the wrong lifestyle and diet, obesity, lack of physical activity, and stress (Sudirman, 2018).

The American Diabetes Association (ADA, 2016) recommends outreach activities to keep knowledge of diabetes in the patient's possession. This independent diabetes management 
differs from traditional DM education. Self-management leads to real action and behavior change (Newman et al., 2004; Gregg et al 2007). Diabetes Self Management Education (DSME) which integrates the four pillars of DM management emphasizes independent behavioral interventions. Researchers have identified several specific skills called selfmanagement that help change various factors related to adherence which in turn can help change lifestyles. DSME uses guidelines, counseling, and behavioral intervention methods to increase knowledge about diabetes and improve individual and family skills in managing DM (Rickheim et al., 2002; Pamungkas et al., 2017). Therefore, in an effort to provide DSME, each session is focused on identifying certain behaviors and providing clear objectives that will later be adopted by people with diabetes, which in turn can optimize glycemic control, avoid acute and chronic complications and optimize the quality of life (Funnell et al., 2008). The purpose of this study was to determine the application of Diabetes Self Management Education (DSME) in patients with type 2 diabetes mellitus based on blood glucose levels.

\section{Methods}

This research is a quantitative study using a pre-experimental design that provides treatment or intervention to the research subjects then the effect of the treatment is measured and analyzed. This design was used to compare the results of the intervention of the application of Diabetes Self Management Education (DSME) on controlling blood glucose levels in patients with type 2 diabetes mellitus in the Limboto Barat Health Center, Gorontalo District before and after treatment.

The research is planned to be carried out for a maximum of one year. The research location in this study was carried out in the West Limboto Health Center Work Area. The sample of this study were patients diagnosed with type II diabetes in the work area of the West Limboto Health Center who met the inclusion criteria set by the researcher. The sampling technique used in this research is probability sampling, which is a sampling technique that provides equal opportunities or opportunities for each element or member of the population to be selected as samples.

\section{Results and Discussion}

\section{Respondent Characteristics}

The following will present an analysis of frequency distribution data based on demographic characteristics including; Age, Gender, Duration of DM, Education Level, and blood glucose levels for people with diabetes at the Limboto Barat Community Health Center for more details can be seen in the following table:

Table 1. Distribution of Respondents According to Variable Characteristics

\begin{tabular}{|c|c|c|c|c|c|c|}
\hline \multirow[t]{2}{*}{ No } & \multirow[t]{2}{*}{ Variable } & \multicolumn{4}{|c|}{$\begin{array}{c}\text { Intervention } \\
(\mathrm{n}=12)\end{array}$} & \multirow[t]{2}{*}{ Total } \\
\hline & & $\begin{array}{l}\text { Mean } \pm \text { SD } \\
(\min -\mathbf{m a x})\end{array}$ & $\mathbf{N}$ & $\%$ & $\mathbf{N}$ & \\
\hline 1 & $\begin{array}{l}\text { Age (Year) } \\
35-44 \\
45-54 \\
55-64 \\
>75\end{array}$ & & $\begin{array}{l}1 \\
4 \\
7 \\
3\end{array}$ & $\begin{array}{l}6,7 \\
26,7 \\
46,7 \\
20,0\end{array}$ & 15 & 100,0 \\
\hline 2 & $\begin{array}{l}\text { Sex } \\
\text { Female } \\
\text { Male }\end{array}$ & & $\begin{array}{l}11 \\
4\end{array}$ & $\begin{array}{l}73,3 \\
26,7\end{array}$ & & \\
\hline
\end{tabular}




\begin{tabular}{|c|c|c|c|c|c|c|}
\hline & & & & & 15 & 100,0 \\
\hline 3 & $\begin{array}{l}\text { Period of DM } 2 \\
<5 \text { Years } \\
5-10 \text { Years } \\
>5 \text { Years }\end{array}$ & & $\begin{array}{l}2 \\
12 \\
1\end{array}$ & $\begin{array}{l}13,3 \\
80,0 \\
6,7\end{array}$ & 15 & 100,0 \\
\hline 4 & $\begin{array}{l}\text { Level of Education } \\
\text { Did not go to school } \\
\text { Elementary School } \\
\text { Junior School } \\
\text { High School } \\
\text { Higher Education }\end{array}$ & & $\begin{array}{l}1 \\
8 \\
1 \\
2 \\
3\end{array}$ & $\begin{array}{l}6,7 \\
53,3 \\
6,7 \\
13,3 \\
20,0\end{array}$ & 更 & 100,0 \\
\hline 5 & $\begin{array}{l}\text { Blood Glucose } \\
\text { Levels } \\
\text { Before Treatment } \\
\text { After Treatment }\end{array}$ & $\begin{array}{c}350,40 \pm 102,46 \\
(212-529) \\
269,20 \pm 73,96 \\
(164-385)\end{array}$ & & & & \\
\hline
\end{tabular}

Source: Primary Data, October 2020

Table 1 shows the characteristics of respondents from 15 respondents based on age, most of them are in the age group 55-64 years, namely 7 people (46.7\%), the most gender is female, namely 11 people (73.3\%), with a long time suffering from type 2 diabetes ( 5-10 years) as many as 12 people (80\%), most of whom have elementary education, namely 8 people $(53.3 \%)$.

While the measurement results of the average blood glucose level before treatment was $350.40 \mathrm{mg} / \mathrm{dL}$, with a standard deviation of 102.46 . The lowest value was $212 \mathrm{mg} / \mathrm{dL}$ and the highest was $529 \mathrm{mg} / \mathrm{dL}$. And the results of measurement of the average blood glucose levels after treatment are $269.20 \mathrm{mg} / \mathrm{dL}$, with a standard deviation of 73.96. The lowest value was $164 \mathrm{mg} / \mathrm{dL}$ and the highest was $385 \mathrm{mg} / \mathrm{dL}$.

\section{Analysis of Differences in Blood Glucose Levels Before And After Treatment}

The following will present an analysis of differences in blood glucose levels in respondents with type II diabetes mellitus in the Limboto Health Center Work Area before and after treatment in the form of giving Diabetes Self Management Education (DSME).

Table 2. Analysis of Differences in Blood Glucose Levels Before And After Treatment

\begin{tabular}{llcccccc}
\hline $\mathbf{N}$ & \multicolumn{1}{c}{ Variable } & $\mathbf{N}$ & Mean & SD & SE & T & P-Value \\
\hline $\begin{array}{l}\text { Blood Glucose } \\
\text { Levels }\end{array}$ & & & & & & \\
$\mathbf{1}$ & $\begin{array}{l}\text { Before } \\
\text { Treatment }\end{array}$ & 15 & 350,40 & $\begin{array}{c}102,4 \\
6\end{array}$ & 26,46 & 4,67 & 0,00 \\
$\mathbf{2}$ & $\begin{array}{l}\text { After } \\
\text { Treatment }\end{array}$ & 15 & 269,20 & 73,96 & 19,1 & & \\
& & & & & & \\
\hline
\end{tabular}

Source: Primary Data, October 2020

Copyright $@$ 2020, Journal of Asian Multicultural Research for Medical and Health Science Study, 
The table above shows that from 15 respondents, the average measurement of blood glucose levels before treatment was $350.40 \mathrm{mg} / \mathrm{dL}$, with a standard deviation of 102.46 . There was a decrease in the average blood glucose levels after treatment, namely $269.20 \mathrm{mg} / \mathrm{dL}$ with a standard deviation of 73.96. From the analysis, it can be concluded that there are significant differences in blood glucose levels in the measurement after giving DSME to the respondents where the $\mathrm{p}$-value is $<0.05$ ( $\mathrm{p}=0.00)$, with a positive $\mathrm{t}$ value (4.67) which indicates that the measurement of glucose levels blood after treatment is smaller than the measurement before treatment.

DSME is a process of providing education to patients regarding the application of self-care strategies independently to optimize metabolic control, prevent complications, and improve the quality of life of DM patients. The DSME process is initially provided by a health professional, while ongoing support can be provided by personnel in community-based practices and resources. DSME is a program designed to address health beliefs, cultural needs, current knowledge, physical limitations, emotional concerns, family support, financial status, medical history, and other factors that affect everyone's ability to meet selfmanagement challenges (Powers et al. ., 2017). The DSME learning level is divided into three levels, namely: (1) Survival / basic level, education is given to patients at this level includes knowledge, skills, and motivation to perform self-care in an effort to prevent, identify and treat short-term complications. (2) Intermediate level, education provided to patients at this level includes knowledge, skills, and motivation to carry out self-care in an effort to achieve recommended metabolic control, reduce the risk of long-term complications and facilitate patient adjustment of life. (3) Advanced level, education provided to patients at this level includes knowledge, skills, and motivation to perform self-care in an effort to support intensive DM management for optimal metabolic control, and full integration into patient life care activities (9).

From the results of the study, there were differences in the mean blood glucose levels in patients with type 2 diabetes mellitus before and after treatment in the form of the application of Diabetes Self Management Education (DSME).

It is hoped that the implementation of educational programs (health education) for people with diabetes will be provided more systematically and continuously containing related materials using interesting educational media and methods to be applied by health service agencies. It is necessary to develop a program to increase the competence of nurses in nursing care for diabetic clients and education related to diabetic self-care to increase the knowledge and skills of nurses in managing diabetes.

\section{Conclusion}

Overall, there were significant differences in blood glucose levels in the measurement after giving DSME to the respondents where the $p$-value was $<0.05(p=0.00)$, with a positive $t$ value (4.67) which indicated that the measurement of blood glucose levels after treatment smaller than the pre-treatment measurement. So that the mean difference in blood glucose levels in patients with type 2 diabetes mellitus before and after DSME treatment can be seen.

\section{References}

Funnell, M. M., Brown, T. L., Childs, B. P., Haas, L. B., Hosey, G. M., Jensen, B., ... \& Siminerio, L. M. (2008). National standards for diabetes self-management education. Diabetes care, 31(Supplement 1), S97-S104.

Perkeni. (2015). Pengelolaan dan pencegahan diabetes melitus tipe 2 di Indonesia. Perkumpulan Endokrinologi Indonesia. 
Powers, M. A., Bardsley, J., Cypress, M., Duker, P., Funnell, M. M., Fischl, A. H., ... Vivian, E. (2017). Diabetes self-management education and support in type 2 diabetes: a joint position statement of the American Diabetes Association, the American Association of Diabetes Educators, and the Academy of Nutrition and Dietetics. The Diabetes Educator, 43(1), 40-53.

Sudirman, A. A. (2018). Diabetes Mellitus, Diabetes Self Management Education (DSME), and Self Care Diabetik. Proceeding The 1 St Gorontalo Internasional Nursing, (ISBN 978-602-6204-10-3).

Patel, D. K., Kumar, R., Laloo, D., \& Hemalatha, S. (2012). Diabetes mellitus: an overview on its pharmacological aspects and reported medicinal plants having antidiabetic activity. Asian Pacific Journal of Tropical Biomedicine, 2(5), 411-420.

Rickheim, P. L., Weaver, T. W., Flader, J. L., \& Kendall, D. M. (2002). Assessment of group versus individual diabetes education: a randomized study. Diabetes care, 25(2), 269274.

Gregg, J. A., Callaghan, G. M., Hayes, S. C., \& Glenn-Lawson, J. L. (2007). Improving diabetes self-management through acceptance, mindfulness, and values: a randomized controlled trial. Journal of consulting and clinical psychology, 75(2), 336.

Newman, S., Steed, L., \& Mulligan, K. (2004). Self-management interventions for chronic illness. The Lancet, 364(9444), 1523-1537.

Pamungkas, R. A., Chamroonsawasdi, K., \& Vatanasomboon, P. (2017). A systematic review: family support integrated with diabetes self-management among uncontrolled type II diabetes mellitus patients. Behavioral Sciences, 7(3), 62.

Bastaki, A. (2005). Diabetes mellitus and its treatment. International journal of Diabetes and Metabolism, 13(3), 111. 